\title{
APPLICATION OF NATURAL COAGULANTS EXTRACTED FROM COMMON BEANS FOR WASTEWATER TREATMENT
}

Scientific paper / Znanstveni rad

Dragana Kukić

(Received: 3 May 2018; accepted: 18 June 2018)

University of Novi Sad, Faculty of Technology Novi Sad, Assistant

Corresponding author: dkukic@uns.ac.rs

Marina Šćiban

University of Novi Sad, Faculty of Technology Novi Sad, Professor

Jelena Prodanović

University of Novi Sad, Faculty of Technology Novi Sad, Assistant professor

Vesna Vasić

University of Novi Sad, Faculty of Technology Novi Sad, Research fellow

Mirjana Antov

University of Novi Sad, Faculty of Technology Novi Sad, Professor

Nataša Nastić

University of Novi Sad, Faculty of Technology Novi Sad, PhD student

\begin{abstract}
In this paper, the possibility of applying natural coagulants obtained from common beans for the removal of colloidal particles from wastewater was investigated. Three types of wastewater were used in the experiments: stillage from bioethanol production, wastewater from sugar production, and synthetic turbid water. Natural coagulants were extracted from crushed beans using $0.5 \mathrm{M} \mathrm{NaCl}$. Jar tests were conducted with different doses of coagulant at different $\mathrm{pH}$ values. After sedimentation, coagulation activity was determined by turbidity measurements. Results showed that the highest coagulation activity of the natural coagulants from common beans was achieved in stillage, at $98.8 \%$ (at pH 9 with applied dose of coagulant of $5 \mathrm{~mL} / \mathrm{L}$ ), while the coagulation activity in the synthetic turbid water was $90.1 \%$ (at pH 8 and a dose of $0.4 \mathrm{~mL} / \mathrm{L}$ ). The lowest coagulation activity was achieved in the wastewater from sugar production, at $49.8 \%$ (at pH 5.5 and dose of $0.4 \mathrm{~mL} / \mathrm{L}$ ).
\end{abstract}

Keywords: natural coagulants; common bean; coagulation activity; wastewater treatment

\section{PRIMJENA PRIRODNOG KOAGULANTA IZ ZRNA GRAHA U POSTUPKU PROČIŠĆAVANJA OTPADNIH VODA}

Sažetak: U ovome je radu ispitivana mogućnost primjene prirodnog koagulanta dobivenog iz zrna graha, za uklanjanje koloidnih čestica iz otpadne vode. Ispitivane su tri različite otpadne vode: otpadna voda iz procesa proizvodnje bioetanola - džibra, otpadna voda iz proizvodnje šećera i model voda. Prirodni koagulant je ekstrahiran iz usitnjenih zrna graha pomoću $0,5 \mathrm{M} \mathrm{NaCl}$. Džar test je napravljen s različitim dozama koagulanta, pri različitim pH vrijednostima vode. Nakon taloženja, određena je koagulacijska aktivnost mjerenjem mutnoće, a za otpadnu vodu iz procesa proizvodnje bioetanola određena je i koagulacijska aktivnost preko KPK. Rezultati su pokazali da se najveća koagulacijska aktivnost postiže za džibru $98.8 \%$ (na pH 9, pri dozi koagulanta od $5 \mathrm{~mL} / \mathrm{L}$ ), dok je u model vodi postignuta aktivnost od $90.1 \%$ (na pH $8 \mathrm{~s}$, dozom od $0.4 \mathrm{~mL} / \mathrm{L}$ ). Najniža koagulacijska aktivnost postignuta je u otpadnoj vodi iz proizvodnje šećera, $49.8 \%$ (na pH 5.5 i pri dozi od $0.4 \mathrm{~mL} / \mathrm{L}$ ).

Ključne riječi: prirodni koagulanti; grah; koagulacijska aktivnost; tretman otpadnih voda 


\section{INTRODUCTION}

Technological and industrial development have enhanced quality of life, but the discharging of various waste streams into the environment and negligence over the past centuries have led to serious air, soil, and water pollution. Nowadays a lot of effort is being made to reduce environmental pollution and to preserve another kind of quality of life - human health.

Consumption of fresh water is increasing, and the sources of clean water are running out. Consequently, wastewater treatment has been imposed as a necessity in order to protect aquatic systems. Various methods can be employed for this purpose, depending on the wastewater's characteristics. One of the basic parameters being determined when wastewater is characterized is its turbidity. The most efficient method for water clarification is coagulation/flocculation. In this process, particles that are too fine to settle form larger settleable flocs through the addition of a coagulant. Usually, coagulation/flocculation is conducted by adding inorganic and synthetic organic coagulants into the water. The most commonly used coagulants are aluminum and iron salts [1]. Aluminum salts are cheap, but there are some indications that residues from these salts can cause Alzheimer's disease [2]. The application of synthetic polymers as coagulants is undesirable, because the residual monomers have neurotoxic and strong carcinogenic properties [3, 4]. Natural coagulants have been used in water treatment for centuries. They have been used in domestic households for traditional water treatment in tropical rural areas [5]. Considering the side effects of the usage of chemical coagulants, natural coagulants have recently become the subject of many studies as an alternative. Their advantages over chemical coagulants are biodegradability, low toxicity, and low residual sludge production [6]. Additionally, natural coagulants can be extracted from plants that are indigenous to the local community.

In a review paper, Choy et al. [7] gave an overview of vegetables and legumes studied as potential sources of natural coagulants. The majority of the summarized plants were legumes from the Fabaceae family, such as the common bean and green pea, which are characteristic of this region. Earlier studies $[8,9]$ showed that crude extracts from common bean seeds exhibit certain coagulation activities, and additional investigations have been carried out in order to improve their efficiency. The results of preliminary studies regarding the determination of possibilities for the practical applicability of natural coagulants in wastewater treatment are shown in this paper. Investigations of natural coagulants are usually conducted in synthetic turbid water. Due to the complex composition of real wastewater, different behaviors are expected of the natural coagulants. Therefore, the focus of this study was to experimentally evaluate the extract efficiency of real samples of wastewater in comparison with the efficiency obtained in synthetic turbid water and, eventually, to establish if it could be used as an aid in primary wastewater treatment. Two real samples of wastewater were used: stillage from bioethanol production and wastewater from sugar production. Synthetic turbid water was prepared from kaolin suspension.

\section{MATERIALS AND METHODS}

\subsection{Extraction of natural coagulants}

Dry seeds of the white common bean (Phaseolus vulgaris) were ground to a fine powder using a laboratory mill and were sieved through a $0.4 \mathrm{~mm}$ sieve in order to obtain a fraction with a particle size less than $0.4 \mathrm{~mm} .5 \mathrm{~g}$ of this fraction were suspended in $100 \mathrm{~mL}$ of $0.5 \mathrm{moL} / \mathrm{L} \mathrm{NaCl}$, and this mixture was stirred on a magnetic stirrer for $10 \mathrm{~min}$. After that, the suspension was filtered through a rugged filter paper (Macherey-Nagel, MN 651/120). Filtrate - crude extract was used as a natural coagulant.

\subsection{Real wastewater}

Studies were carried out on samples of real wastewater - from bioethanol and sugar production processes. Individual samples of both types of wastewater were taken from the first wastewater collecting tank (total $100 \mathrm{~L}$ ), and then they were homogenized and analyzed. Small portions of the homogenized sample (5L) from bioethanol/sugar production were kept in a freezer and were used in a series of studies.

Analyses of the stillage from bioethanol production used in this investigation (Table 1) were conducted after homogenization of the individual samples, and these results have already been reported by Vasić et al. [10]. The stillage came from ethanol production with starchy raw materials (stale bread and wheat).

Kukić, D, Šćiban, M, Prodanović, J, Vasić, V, Antov, M, Nastić, N 
Table 1 Results of the analysis of stillage from bioethanol production [10] Parameter

\begin{tabular}{lc}
\hline $\mathrm{pH}$ & 3 \\
Suspended solids $(\mathrm{mg} / \mathrm{L})$ & 18340 \\
Chemical Oxygen Demand $\left(\mathrm{mg} \mathrm{O}_{2} / \mathrm{L}\right)$ & 102000 \\
Turbidity (NTU) & 7764
\end{tabular}

The same parameters were determined for the wastewater obtained from sugar production. $\mathrm{pH}$, suspended solids, and chemical oxygen demand were determined according to Standard Methods [11]. Turbidity was measured using a turbidimeter (WTW TURB 550/550 IR), and it was expressed in nephelometric turbidity units (NTU).

\subsection{Preparation of synthetic turbid water}

Synthetic turbid water for coagulation tests was prepared by adding stock kaolin suspension into tap water. The stock kaolin suspension contained $10 \mathrm{~g}$ of kaolin in $1 \mathrm{~L}$ of tap water. This kaolin suspension was added in sufficient amounts to tap water in order to achieve an initial turbidity of 170 NTU.

\subsection{Coagulation tests}

The coagulation activity of natural coagulants was evaluated using the jar tester VELP (FC6S) in stillage from bioethanol production, wastewater from sugar production, and synthetic turbid water at room temperature. A natural coagulant was added to $600 \mathrm{~mL}$ of a sample at different $\mathrm{pH}$ values. Coagulation tests were conducted at the original $\mathrm{pH}$ and $\mathrm{pH} 6$ and 9 for stillage; the original $\mathrm{pH}$, and $\mathrm{pH} 6$ and 8 for wastewater from sugar production; and $\mathrm{pH} 5.5,7$, and 9 for the model water. The $\mathrm{pH}$ was adjusted using $\mathrm{HCl}$ or $\mathrm{NaOH}$ solutions. Different doses of natural coagulants were also applied: $5,10,20$, and $40 \mathrm{~mL} / \mathrm{L}$ for real samples; and $0.2,0.4,0.6$, and $0.8 \mathrm{~mL} / \mathrm{L}$ for model water. The content was stirred at $200 \mathrm{rpm}$ for $1 \mathrm{~min}$. The mixing speed was then reduced to $60 \mathrm{rpm}$ and was kept for $30 \mathrm{~min}$. The suspensions were finally allowed to settle. After $1 \mathrm{~h}$ of sedimentation, upper clarified liquid was collected, and residual turbidity was measured. The same coagulation test was performed with no coagulant as a blank. Coagulation activity was calculated as:

Coagulation activity $(\%)=(($ RTB - RTS $) /$ RTB $) \cdot 100$

RTB - residual turbidity of the blank

RTS - residual turbidity of the sample

For the monitoring of coagulation activity, turbidity was chosen, because natural coagulants from the common bean would be potentially useful in improving precipitation in the primary settler.

\section{RESULTS AND DISCUSSION}

\subsection{Analysis of wastewater from sugar production}

The results of the analysis of wastewater from sugar production are shown in Table 2. It can be concluded that the composition of real wastewater is very different from that of stillage. Suspended solids in wastewater from sugar production mainly originate from the sand and soil from the roots of the sugar beet, while suspended solids in stillage originate from the remains of starchy raw material used in bioethanol production. Although the content of suspended particles in the two types of wastewater is similar, there could be a major difference regarding COD and turbidity due to the nature of the particles. Nevertheless, organic matter in wastewater from sugar production mainly originates from sugar and other extractives extracted from the sugar beet roots during washing, which generally have low molecular mass. There are no sugars in the stillage, but it contains insoluble residues of raw materials and yeast cells, plus various organic molecules (e.g. proteins) of lower molecular mass. Therefore, stillage has a very high polydispersity index [12]. Due to the different and complex compositions of these samples, the coagulation activity of natural coagulants is expected to be different. 
Table 2 Results of the analysis of wastewater from sugar production Parameter

\begin{tabular}{lc}
\hline $\mathrm{pH}$ & 5,9 \\
Suspended solids (mg/L) & 13675 \\
Chemical Oxygen Demand $\left(\mathrm{mg} \mathrm{O}_{2} / \mathrm{L}\right)$ & 15548 \\
Turbidity (NTU) & 170
\end{tabular}

\subsection{Treatment of stillage from bioethanol production}

Owing to the great influence of solution $\mathrm{pH}$ on coagulation activity, coagulation tests were performed on the different $\mathrm{pH}$ values: original (3.32), 6 , and 9 [13]. The applied dose of coagulant was $10 \mathrm{~mL} / \mathrm{L}$, and it was chosen based on previous investigations of coagulation activity of natural coagulants from the common bean [10]. The initial turbidity of stillage was 7764 NTU. After sedimentation in upper clarified liquid, turbidity was measured, and coagulation activities were calculated. The results are shown in Figure 1.

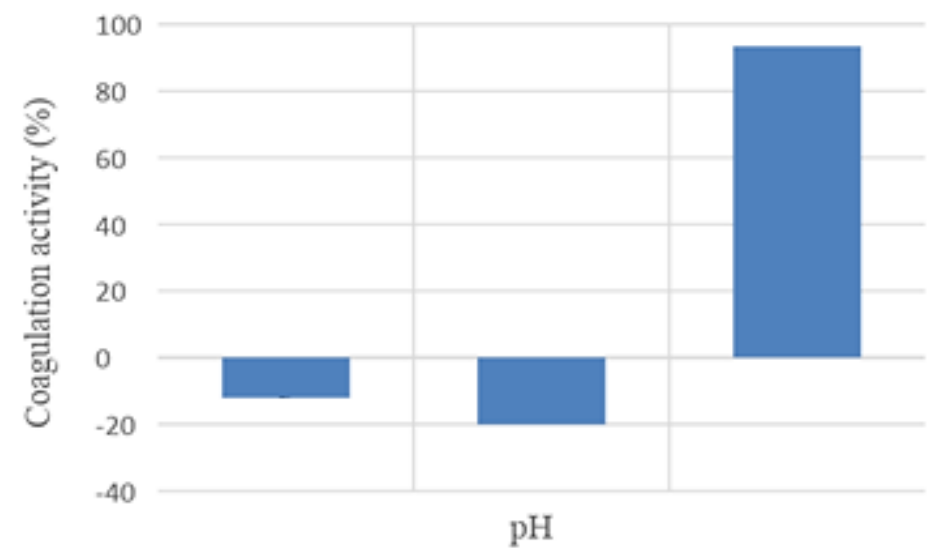

Figure 1 Coagulation activity of natural coagulants at different stillage $\mathrm{pH}$ values

Coagulation activity of extracts of the common bean in stillage from bioethanol production was highest at $\mathrm{pH}$ 9 (over 93\%). Adding coagulant at lower pH values resulted in an increase of wastewater turbidity. Namely, coagulation activities at pH 3.32 and 6 were negative. Turbidity is caused by the presence of suspended solids. In stillage, suspended solids contain $94 \%$ of organic matter [10] therefore, it can be concluded that the content of organic matter in the clarified stillage would be significantly reduced. A similar trend in the decrease of organic matter was observed when the natural coagulant obtained from the common bean was used for the treatment of sugar beet extraction juice stillage [13]. It is known that $\mathrm{pH}$ has a great influence on coagulation. This is even more complicated in real wastewater, which contains many different substances that can react with each other or with the natural coagulant. Since the coagulation activity was highest at $\mathrm{pH} \mathrm{9}$, the investigation of the influence of different doses of applied coagulant was carried out with this $\mathrm{pH}$ value (Figure 2).

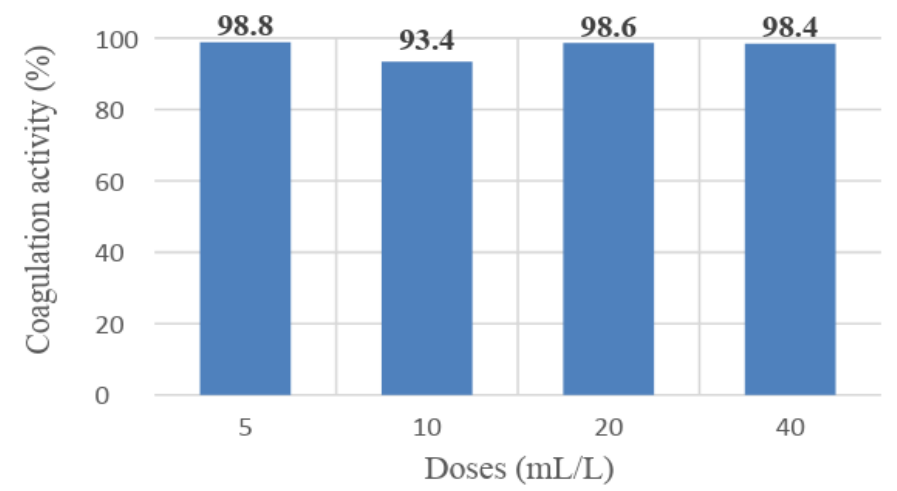

Figure 2 Coagulation activities of different doses of natural coagulant in stillage

Kukić, D, Šćiban, M, Prodanović, J, Vasić, V, Antov, M, Nastić, N 
Contrary to the results obtained in the investigation of the influence of applied coagulant dosage on the organic matter content of treated sugar beet extraction juice stillage [13], applied dosage of natural coagulant showed low influence on coagulation activity at this $\mathrm{pH}$. All studied doses of common bean extract showed very high coagulation activity in stillage from bioethanol production. A dosage of $10 \mathrm{~mL} / \mathrm{L}$, as was used in previous experiments, had the lowest activity. All other doses showed coagulation activity over $98 \%$. This high coagulation activity is an excellent result, especially when the natural coagulant is applied to a real sample of wastewater. This shows its great potential in the practical application of wastewater treatment.

\subsection{Treatment of wastewater from sugar production}

The original $\mathrm{pH}$ of the wastewater from sugar production was 5.97 , and the initial turbidity was 174 NTU. Coagulation tests on different $\mathrm{pH}$ values $(5,6$, and 9$)$ were conducted with a coagulant dose of $0.4 \mathrm{~mL} / \mathrm{L}$. The results are shown in Figure 3.

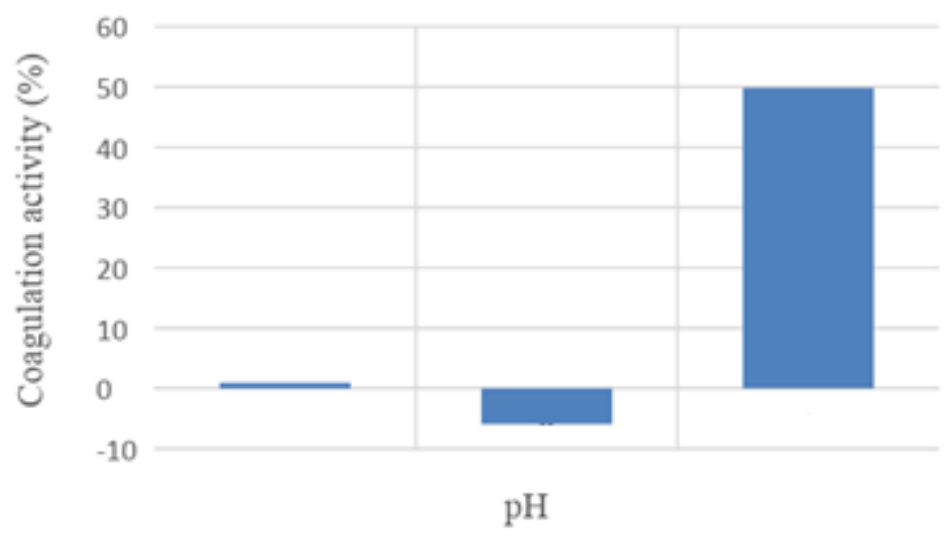

Figure 3 Coagulation activity of the natural coagulant at different $\mathrm{pH}$ values of wastewater from sugar production

There is almost no coagulation activity at $\mathrm{pH} 5$, while at $\mathrm{pH} 6$ the turbidity of wastewater increased after the addition of a natural coagulant. The best coagulation activity was achieved at $\mathrm{pH} 8$, at $49.8 \%$. The efficiency of turbidity removal was not as high as was the case with the stillage treatment, but it was satisfying.

The investigation of the influence of applied coagulant dosage was carried out at $\mathrm{pH} 8$. The results of these experiments are shown in Figure 4.

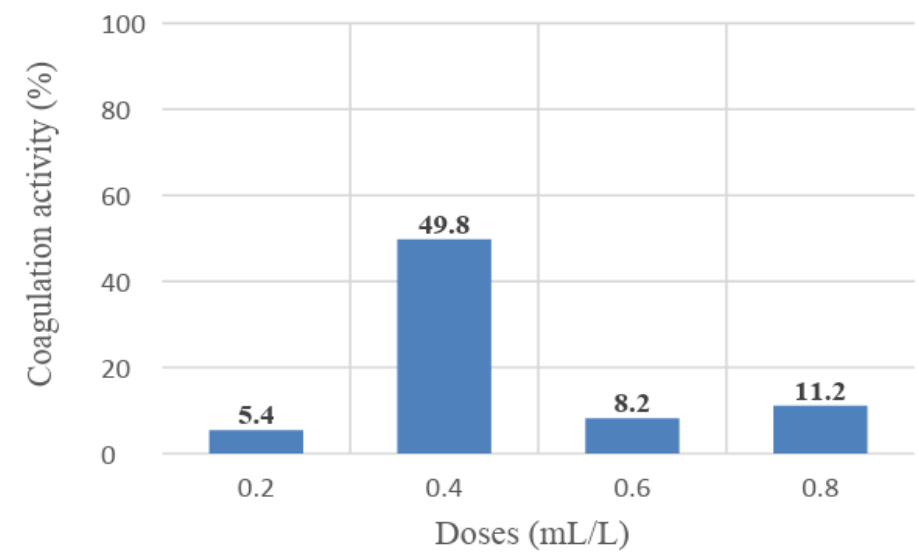

Figure 4 Coagulation activities at different doses of natural coagulant in wastewater from sugar production

It was observed that the dose of $0.4 \mathrm{~mL} / \mathrm{L}$ resulted in the best coagulation activity compared to the other applied doses. Therefore, this dose can be recommended for treatment of this particular wastewater. Moreover, 
this dose is about twelve times lower than the one that showed the highest coagulation activity in the stillage. This fact can be explained by the significantly lower initial turbidity of the wastewater from sugar production compared with that of the stillage.

The results of the wastewater treatment with natural coagulants showed that turbidity removal is more efficient in stillage from bioethanol production, probably due to the presence of different substances in wastewaters that can interfere with coagulants.

\subsection{Treatment of synthetic turbid water}

The initial turbidity of synthetic turbid water was adjusted to 170 NTU in order to achieve a turbidity similar to that of wastewater from sugar production. Coagulation activities at different $\mathrm{pH}$ levels and different coagulant doses were investigated. In coagulation tests at different $\mathrm{pH}$ levels $(5.5,7$, and 9 ) a coagulant dose of $0.4 \mathrm{~mL} / \mathrm{L}$ was used. The results are shown in Figure 5.

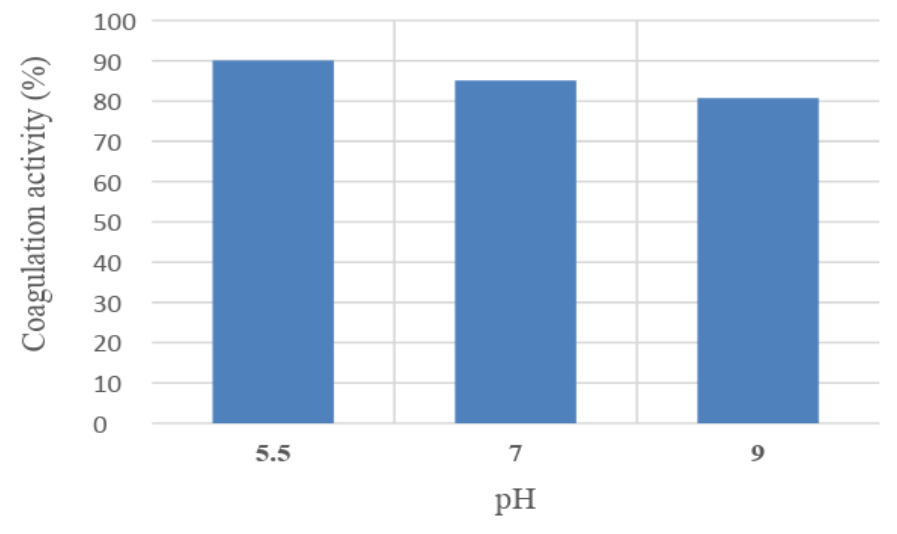

Figure 5 Coagulation activity of the natural coagulant at different $\mathrm{pH}$ values for the synthetic turbid water

At all studied $\mathrm{pH}$ values, the coagulant showed high activity (over $80 \%$ ). The best coagulation activity was achieved at pH $5.5(90.1 \%)$. Therefore, the investigation of adequate coagulant dosage was conducted at that pH level (Figure 6).

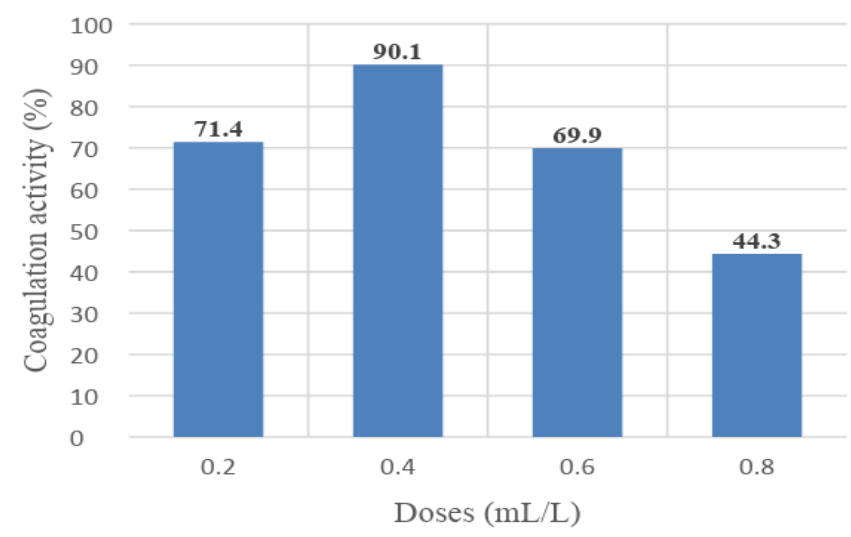

Figure 6 Coagulation activities of different doses of the natural coagulant in synthetic turbid water

The best coagulation activity was achieved with a dose of $0.4 \mathrm{~mL} / \mathrm{L}$. Synthetic turbid water was prepared from tap water and kaolin suspension. Its composition is not as complex as that of real wastewaters; thus, different coagulation activities are expected for these mediums.

The investigation of natural coagulant is topical, and many biomaterials were studied as potential sources of natural coagulants. Few findings comparable to the results presented in this paper could be found in the available literature. Maurya and Daverey [14] applied plant-based natural coagulants to municipal wastewater treatment: 
banana peel powder, neem leaf powder, papaya seed powder, and banana stem juice. Experiments were conducted at room temperature using the original $\mathrm{pH}$ of the wastewater. Different dosages were applied, and the highest coagulation activity was seen with the banana peel powder at $59.6 \%$, with a dose of $0.4 \mathrm{~g} / \mathrm{L}$. The authors also observed that higher coagulant doses had negative impacts on coagulation activity. The strychnos potatorum coagulant used for turbidity removal from the wastewater generated during a car wash decreased turbidity by over $90 \%$ with a dose of $30 \mathrm{mg} / \mathrm{l}[15]$.

Due to the complexity of wastewater composition and the numerous factors that can influence coagulation activity, it is necessary to determine the optimal conditions for achieving satisfying results in the usage of coagulants in the practice of wastewater treatment.

\section{CONCLUSIONS}

This paper investigated the coagulation activity of the natural coagulant extracted from the common bean in different wastewaters and in model water. The results showed that the best coagulation activity $(98.8 \%)$ in stillage from bioethanol production was achieved at $\mathrm{pH} 9$ and with a coagulant dose of $5 \mathrm{~mL} / \mathrm{L}$. In wastewater with a lower $\mathrm{pH}$, the addition of coagulant increased turbidity. The best wastewater treatment result from sugar production was at a dose of $0.4 \mathrm{~mL} / \mathrm{L}$ at pH 8 . Under these conditions, the coagulation activity was $49.8 \%$. The natural coagulant from the common bean showed high coagulation activity $(90.1 \%)$ in model water at pH 5.5 and a dose of $0.4 \mathrm{~mL} / \mathrm{L}$.

Based on these results, it can be concluded that the results of coagulation tests obtained from the experiments in model water cannot be directly applied to real wastewaters. Real wastewaters are complex and can contain different interfering substances that can affect the coagulation process. The application of the investigated coagulant to real wastewaters requires additional investigation.

\section{Acknowledgement}

These investigations were carried out in the frame of project number 142-451-2456/2018-01/02, which was financially supported by the Secretariat of Science and Technological Development of the Province of Vojvodina, Republic of Serbia, as well as project number TR 31002, which was financially supported by the Ministry of Education, Science, and Technological Development of the Republic of Serbia.

\section{References}

[1] Okuda T; Aloysius UB; Wataru N; Okada M 1999: Improvement of extraction method of coagulation active components from Moringa oleifera seed, Water Research, 33 (15), pp 3373-3378, https://doi:10.1016/S00431354(99)00046-9

[2] Flaten TP 2001: Aluminium as a risk factor in Alzheimer's disease, with emphasis on drinking water, Brain Research Bulletin, 55, pp. 187-196

[3] Chico Galdo V; Massart C; Jin L; Vanvooren V; Caillet-Fauquet P; Andry G; Lothaire P; Dequanter D; Friedman M; Van Sande J 2006: Acrylamide, an in vivo thyroid carcinogenic agent, induces DNA damage in rat thyroid cell lines and primary cultures, Molecular and Cellular Endocrinology, 257-258, pp. 6-14, https://doi:10.1016/..mce.2006.06.003

[4] Zahrim AY; Tizaoui C; Hilal N 2011: Coagulation with polymers for nanofiltration pre-treatment of highly concentrated dyes: A review, Desalination, 266 (1-3), pp. 1-16, https://doi:10.1016/i.desal.2010.08.012

[5] Fuglie LJ 2001: The miracle tree - The multiple attributes of Moringa, Technical Centre for Agricultural and Rural Cooperation (CTA)/Church World Service (CWS), New York

[6] Narasiah K; Vogel SA.; Kramadhati NN 2002: Coagulation of turbid waters using Moringa oleifera seeds from two distinct sources, Water Science and Technology: Water Supply, 2, pp. 83-88

[7] Choy SY; Prasad KMN; Wu TY; RamananInt RN 2015: A review on common vegetables and legumes as promising plant-based natural coagulants in water clarification, International Journal of Environment Science and Technology, 12, pp. 367-390, https://doi:10.1007/s13762-013-0446-2

Kukić, D, Šćiban, M, Prodanović, J, Vasić, V, Antov, M, Nastić, N

https://doi.org/10.13167/2018.16.7 
[8] Šćiban M; Klašnja M; Stojimirović J 2005: Investigation of coagulation activity of natural coagulants from seeds of different leguminose species, Acta Periodica Technologica, 36, pp. 1-266, https://doi: 10.2298/APT1041141S

[9] Antov M; Šćiban M; Prodanović J 2012: Evaluation of the efficiency of natural coagulant obtained by ultrafiltration of common bean seed extract in water turbidity removal, Ecological Engineering, 49, pp. 48-52, https://doi.org/10.1016/i.ecoleng.2012.08.015

[10] Vasić V; Prodanović J; Kukić D; Antov M; Ivetić D 2013: Application of membrane and natural coagulants for stillage purification, Desalination and Water Treatment, 51, pp. 437-441, https://doi.org/10.1080/19443994.2012.714525

[11] APHA (American Public Health Association) 1998: Standard methods for the examination of water and wastewater, 20th ed., APHA, AWWA, WEF, Washington DC

[12] Vasić V 2013: Purification of wastewater from bioethanol production process by microfiltration. PhD Thesis, Faculty of Technology Novi Sad, Novi Sad.

[13] Prodanović J; Šćiban M; Antov M; Kukić D; Vasić V 2015: Treatment of sugar beet extraction juice stillage by natural coagulants extracted from common bean, Acta Periodica Technologica, 46, pp. 77-89, https://doi: 10.2298/APT1546077P

[14] Maurya S; Daverey A 2018: Evaluation of plant-based natural coagulants for municipal wastewater treatment, 3 Biotech, 8 (1), pp. 77, https://doi:10.1007/s13205-018-1103-8

[15] Radin Maya Saphira Radin M; Nadira MA; Ibrahim K; Amir HMK 2014: Efficiency of using commercial and natural coagulants in treating car wash wastewater, Australian Journal of Basic and Applied Sciences, 8 (16), pp. 227-234

Please cite this article as:

Kukić, D, Šćiban, M, Prodanović, J, Vasić, V, Antov, M, Nastić, N: Application of natural coagulants extracted from common beans for wastewater treatment, Electronic Journal of the Faculty of Civil Engineering Osijek-eGFOS, 16, pp. 77-84, https://doi.org/10.13167/2018.16.7 